\title{
HOW TO INCREASE PRODUCTION OF BEEF, LAMB AND PORK IN SERBIA FOR DOMESTIC MARKET AND EXPORT
}

\author{
M. M. Petrovićn ${ }^{1}$ M. P. Petrović ${ }^{1}$, M. Petrović ${ }^{2}$, S. Aleksić ${ }^{1}$, D. Ostojić-Andrić1, \\ V. Pantelić1 ${ }^{\text {Z }}$. Novaković1 \\ ${ }^{1}$ Institute for Animal Husbandry, Autoput 16, P. Box 23, 11080 Belgrade-Zemun, Republic of Serbia \\ ${ }^{2}$ Faculty of Agriculture, 11080 Belgrade-Zemun, Republic of Serbia \\ Corresponding author: Milan M. Petrović, E-mail: milpet99@yahoo.com \\ Invited paper
}

\begin{abstract}
The present situation in livestock production and production of meat is presented in this paper, as well as directions for future work aimed at bringing changes to this branch of economy. In the last decade, a drop in the number of animals was recorded of approx. 2 to $3 \%$ at annual level. Also, drop in production of meat was recorded from 444.000 tons (1990) to 384.000 tons (2010). In order to have planned progress in production of meat it is necessary to define more clearly breeding goals with precise determination of all economically relevant and indicator traits. In addition to growth and body development traits which have so far been in focus of selection work, for production of meat also maternal traits are important, food conversion and quantity and quality traits of carcasses and meat.
\end{abstract} animals

Key words: cattle, sheep, pig, meat, selection, farm, cow, milk, number of

\section{Introduction}

Share of livestock production in total agricultural production and number of animal units per ha of agricultural indicate the level of development of agriculture of one country. Below $35 \%$ of livestock production in total agriculture indicates under-developed agriculture as branch of economy of one country. In order to be able to compete with other countries, we need to find another way to use all natural resources of 5,1 million hectares of agricultural land $(0,60$ hectares per capita). In the last decade a drop in number of farm animals of 2 to $3 \%$ at annual level was recorded. Also, drop in production of meat was recorded from 444.000 tons (1990) to 384.000 tons (2010). 
Table 1. Production of different meat types (in 000 tons)

\begin{tabular}{||l||c||c||c||c|}
\hline Year & Beef & Mutton & Pork & Total produced \\
\hline \hline 1990. & 139 & 23 & 282 & 444 \\
\hline \hline 2000. & 104 & 19 & 283 & 406 \\
\hline \hline 2010. & 92 & 23 & 269 & 384 \\
\hline
\end{tabular}

Source: Statistical Office of the Republic of Serbia

Reasons for this negative trend were different, but together they are product of reduced domestic market, lower purchasing power of the population, loss of previous markets for our products in Europe and World, transition and privatisation, absence of the 3 key factors (quantity, quality and continuity in production), absence of organization of primary production and poor links between primary and processing sector, situation in regard to genetics in cattle, sheep and pig rearing, etc. Of course, great obstacle for export to EU countries are very strict regulations in these countries for import of food from „third“ countries and competition dominated by quality and price.

\section{Development of primary livestock production}

The long-term goals in development of livestock should be based on: development of market oriented production (commodity farmers), production of sufficient quantities of all livestock products for population, supply of all livestock products at prices and of quality adjusted to the purchasing power of the population, production for export, ensuring more stable domestic market (government measures), application of scientific-research achievements and protection of the environment. The long-term concept of livestock development should be founded on efficiency in production of meat, through farmer associations and organizations. For successful organizational and economical strengthening of farmers it is important to choose form of business associating which provides business efficiency, modern technology, rational use of common resources (equipment, machines, etc.), financial short-term assets to credit current production, supplies/inventory and marketing of products. For hilly-mountainous regions of Serbia, where there are no purchasing or processing capacities, and which are located far away from urban centres, one form of farmer associations could be mini processing facilities - mini-dairy plants and mini-slaughterhouses. These regions can successfully produce all types of meat and dairy products with special indications such as "biologically high value" food and sold in big retail chains or centres or exported to foreign markets (Petrović M. M. et al., 1997, 2000, 2001, 2005).

For faster and economically more efficient production of meat, as well as faster and more efficient organizing and associating of farmers, basically, it is 
necessary to solve first all problems which have had in the past, and still have, destabilizing effect on total livestock production, motivation of farmers, purchasing power of the consumers and regulars supply to the market, and those factors are policy of the market and prices, credit policy and policy of subsidies and incentives. Stable prices of livestock products determined in advance, as well as adequately determined price parities, are guarantee for stable livestock production, of supply of livestock products to the domestic market and possibility for export of meat and live animals of high quality. Previous experiences in livestock improvement and results achieved in the world, transfer of technologies, etc., suggest that for total improvement of livestock production better organization and improved scientific and expert infrastructure are necessary.

\section{Improvement in production of beef, mutton and pork}

In Serbia, in 2010, in spite of decrease in number of farm animals, total of 384.000 tons of beef, pork and lamb meat was produced, which is by $3,3 \%$ more than in 2009 , i.e. by $6,3 \%$ more compared to average production from 2001 to 2009. In Serbia, in 2010, production of beef, young beef and veal was lower by 4,4 $\%$, and of mutton and lamb meat by $7,1 \%$, and production of pork increased by $6,8 \%$. In 2010 , in comparison to average realized production in period 2001 to 2009 , more of all types of meat were produced: pork by $3,1 \%$, beef and young beef by $7,5 \%$ and mutton and lamb meat by $15 \%$.

Number of cattle in the last decades, and especially in the first decade of the $21^{\text {st }}$ century, shows the tendency of decrease. However, this should not be of great concern, since by application and utilization of new techniques and technologies, as well as organizing of commodity farmers, the production in the existing cattle population can be intensified per animals and in total.

Table 2. Number of cattle according to categories (in 000)

\begin{tabular}{|l||c||c||c||c||c||c||}
\hline \hline & 1991. & 2000. & 2006. & 2007. & 2008. & 2010. \\
\hline \hline Cattle TOTAL & 1.483 & 1.246 & 1.106 & 1.087 & 1.057 & 938 \\
\hline \hline Cows & 847 & 759 & 622 & 602 & 578 & 498 \\
\hline \hline Fattening cattle & 168 & 118 & 223 & 187 & 216 & 185 \\
\hline
\end{tabular}

Source: Statistical Office of the Republic of Serbia

\section{Breed structure and improvement of cattle}

Domestic spotted cattle of Simmental type and Simmental breed make approx 75\%, the group of Black and White and Red and White cattle around 20\%, and remaining breeds make $5 \%$ of total number of cattle in Republic of Serbia. In 
order to have planned progress in production of meat it is necessary to define more clearly breeding goals with precise determination of all economically relevant and indicator traits. In addition to growth and body development traits which have so far been in focus of selection work, for production of meat also maternal traits are important, food conversion and quantity and quality traits of carcasses and meat. Considering that in future the production of beef in Serbia will predominantly be organized as dual purpose cattle rearing, selection for milk performance/traits should not cause any disruption of already achieved level of phenotypic expression of milk traits, because in existing production conditions in Serbia, dual purpose cattle, and especially Simmental breed, should provide production of milk and production of meat.

One possible way to improve fattening and slaughter traits of domestic Simmental cattle is systematic crossing with fattening breeds - animals obtained from crossing of domestic cows of lower production performance with bulls of fattening breeds - French (Charolais, Limousine, Blonde d'Aquitaine), Italian (Chianina, Piemontese), English (Aberdeen Angus, Galloway, Hereford). Breeding goals of such breeding work and use of the heterosis effect are creation of genotypes which will result in final body mass of F1 crosses of over $550 \mathrm{~kg}$, average daily gain in fattening of over $1500 \mathrm{~g}$, dressing percentage/meat yield of warm carcasses of over $60 \%$, muscle content in carcass of over $65 \%$ (Aleksić et al., 2006; Miščevič et al., 2006; Petrović M. M. et al., 2007).

\section{Cattle housing system and organization of farm production}

All holdings which are seriously engaged in cattle production should in future period be organized as holdings (farms) for market production of milk, holdings (farms) for market production of fattening cattle and holdings (farms) for combined market production of milk and slaughter cattle.

Holdings (farms) for market production of fattening cattle. Tradition of cattle fattening by our farmers is quite known, as well as the quality of beef (baby beef). These holdings (farms) should be organized in private ownership and on holdings with in average over eight hectares of plough land and meadows.

Holdings (farms) for combined market production of milk and fattening cattle. These combined farms can successfully be organized in low land and hilly-mountainous regions, with sufficient quantities of animal food of high quality or concentrated food. Such farms could be organized in holdings with over 30 hectares of plough land or meadows. This group of farmers will mainly comprise farmers from hilly-mountain regions, so this system of cattle rearing will also be in function of achieving better economical effect per animal. 


\section{Improvement of production of lamb meat, number of sheep and breed structure}

Sheep rearing is mainly realized by small family holdings (farms) in flocks of 10 to 15 animals, from 70 to 100 , and on fewer farms from 200 to 500 .

Table 3. Number of sheep according to categories (in 000)

\begin{tabular}{|l||c||c||c||c||}
\hline \hline Year & TOTAL & Sheep below 1 year & Breeding sheep & Rams and barren sheep \\
\hline \hline 1991. & 2.127 & 419 & 1.588 & 121 \\
\hline \hline 2010. & 1.475 & 231 & 1.049 & 99 \\
\hline
\end{tabular}

Source: Statistical Office of the Republic of Serbia

In regard to the breed structure, different strains of Pramenka breed make approx. $70 \%$ of total number of sheep, different types of crosses around $23 \%$, Tsigai around 5\% and approx. 2\% of imported pure breeds used for improvement o of existing population.

The following sheep strains are reared on the territory of Republic of Serbia: Sjenica strain, Svrljig strain, Pirot strain and population of improved Pirot sheep. Following by Tsigai, and various more or less often crosses of different Pramenka strains, and Merino breed for meat and wool or wool and meat, as well as commercial flocks. Of imported pure breeds used for improvement of existing population the main breed used was Merinolandschaf (Wurttemberg) as general improver of domestic Pramenka strains, and still flocks exist of pure breed animals, also Ile de France, Bergamo, and Suffolk breeds used to improve the existing population in regard to yield and quality of meat.

Improvement/breeding of sheep for the purpose of increase of meat yield. In order to achieve certain genetic improvement in sheep production of Serbia, it is necessary to execute programmed selection of reared breeds. Considering that the variability of quantitative traits within single population is pronounced and that certain number of individual animals ( + variants) realize above average results, selection experts in countries where sheep production is developed, have formed so called nucleus flocks (selection core), as outline of future development of sheep production.

For the purpose of production of meat, in addition to breeding and selection in pure breed, it will be necessary to apply method of crossing and utilization of heterosis effect, but also creation of new more productive sheep breeds. This includes the following: crossing of domestic Pramenka with rams of Merinolandschaf breed; - breeding of optimal combinations of crosses of these two breeds; - crossing of two breed crosses with third terminal breed of meat type (Il de France) in order to improve fattening properties of lambs; - crossing of Tsigai 
breed with rams of meat breeds (Suffolk, Il de France, etc.); - creating new breeds of sheep used for production of meat (Petrović P. M. et al., 2009).

Improvement aimed at increase of meat production should ensure obtaining of lambs with higher daily gain (over 300 g), higher final body mass at the age of 90 days (over $28 \mathrm{~kg}$ ), as well as higher carcass dressing percentage of over $58 \%$.

Production of lambs for fattening. Solving of the problem of sheep reproduction, and at the same time of production of lambs for export ad domestic market, in Serbia, will continue to be priority in sheep production. Lambing system should be organized in such manner to ensure more gravidity and lambings during the productive life of sheep and more lambs per single partus. Problem associated with poly cyclic system and breeding of sheep throughout the year could be solved in two ways: genetically, using crossing of breed which manifest oestrus outside normal season (Dorzet Horn, Il de France and Romanovska sheep) by method of stimulation, i.e. oestrus induction and synchronization. In this way conditions are created for application of the intensive system of lambing - two parities in one year, i.e. three in two years.

The system of lambing, of crossing, selection and line breeding, also shortening of post partum interval and increase of lambing index, as well as of number of lambs at birth, early weaning of lambs, artificial insemination, automatic suckling machines, rearing of lambs using milk replacers and fattening of lambs from 30 to $45 \mathrm{~kg}$ in 90 to 120 days, will be basis of modern technology in sheep breeding.

\section{System of sheep housing and organization of farm production}

Main focus in programs for development of this branch of livestock production should be directed to family holdings (farms) and new technologies for intensive production of meat, milk and wool on sheep farms.

Genetic centres, nucleus flocks should be established where under the supervision of scientists and experts, all activities aimed at genetic improvement of sheep in Serbia would be carried out.

Specialized farmers for meat and milk production should have from 100 to 500 sheep, as well as adequate infrastructure. They would be the major commodity producers for the market. Specialized farmers will base their production on genetic material obtained through selection and breeding work on big farms, and for the purpose of more efficient use of this material new, modern technologies will be used. Farmers engaged in triple purpose production traditionally have 20 to 50 sheep and they need high quality breeding material and all possible assistance to increase their production. 


\section{Improvement of production of pork, number of animals and breed structure}

Main product of modern organized pig production is high quality pork. It is at the same time raw material for further processing. In addition to series of significant pig traits, one of them, which make it different from other farm animals, is significant quantity of meat which can be produced per sow annually (over 2000 $\mathrm{kg}$ of live weight or over $1600 \mathrm{~kg}$ in carcass sides or over $800 \mathrm{~kg}$ of meat). Significance of pig production in the World, Europe and Serbia is confirmed by the data that of total production of meat in the world, 40 to $50 \%$ is pork.

Table 4. Number of pigs according to categories (in 000)

\begin{tabular}{|l||c||c||c||c||c||}
\hline Year & TOTAL & Sows & Gravid gilts & Breeding boars & Fatteners \\
\hline \hline 1991. & 4.263 & 708 & 168 & 35 & 1.023 \\
\hline 2010. & 3.489 & 405 & 111 & 22 & 899 \\
\hline
\end{tabular}

Source: Statistical Office of the Republic of Serbia

In our pig herds, Landrace breeds are reared (Swedish, Dutch, Belgium, Danish, German), Large Yorkshire, Duroc and Pietrain. Most animals are of Swedish Landrace and Large Yorkshire breed. Share of meat breeds used as terminal breeds in crossing (Belgian Landrace, German Landrace, Pietrain, Hampshire, Duroc) is small (less than $1 \%$ individually each breed). In addition to pure breeds, also crosses are reared which make over $60 \%$ of total number of sows.

Improvement/breeding of pigs for increase of meat yield. Program of breeding-selection work should enable further improving of fertility traits, growth rate, feed efficiency, carcass quality (higher percentage of muscle tissue in carcass), meat quality and resistance of pigs to diseases and stress.

Constant, systematic and planned breeding-selection work should results in increase of the genetic potential of existing meat pig breeds and crosses, creation of lines within pure breeds through use of divergent selection, in order to have greater heterosis effect in their later use in pig crossing.

Selection goal should be increase of muscle tissue in major carcass parts: leg, shoulder and loin. Breeding program in our country anticipates crossing of Landrace (Swedish, Dutch, etc.) and Large Yorkshire in production of $F_{1}$ generation of gilts, which are later to be used in crossing with boars of third breed (terminal boar breed: Hampshire, Duroc, Pietrain, German and Belgian Landrace) or boars of $\mathrm{F}_{1}$ generation (Petrović et al., 2006). 


\section{System of pig housing and organization of farm production}

In future, holdings/farms should be carriers of pig production, but not in the sense of number of pigs, since they are already dominant in this respect, but also in production of high quality fatteners.

Holdings/farms for production of pigs for the market. Family farms could in future ten year period house 50 and subsequently 100 sows and have over 1000 pigs in fattening. This could result in increase of production of pork at average annual rate of 2 to $2,5 \%$.

It is necessary to select the best farmers to form the elite, reproduction and production (commercial) herds within pyramid organization of production of breeding animals and fatteners. This is necessary since it is not clearly defined which farms can produce high quality breeding sows and boars, what ratio should be considering the number of pigs and direction of pigs from the top to the bottom of the pyramid, in order to achieve greater genetic progress.

\section{Conclusion}

The present situation in livestock production and production of meat is presented in this paper, as well as directions for future work aimed at bringing changes to this branch of economy. In the last decade, a drop in the number of animals was recorded of approx. 2 to $3 \%$ at annual level. Also, drop in production of meat was recorded from 444.000 tons (1990) to 384.000 tons (2010). In order to have planned progress in production of meat it is necessary to define more clearly breeding goals with precise determination of all economically relevant and indicator traits. In addition to growth and body development traits which have so far been in focus of selection work, for production of meat also maternal traits are important, food conversion and quantity and quality traits of carcasses and meat.

Number of cattle, sheep and pigs in the last decades, and especially in the first decade of the $21^{\text {st }}$ century, shows the tendency of decrease. However, this should not be of great concern, since by application and utilization of new techniques and technologies, as well as organizing of commodity farmers, the production in the existing populations of farm animals can be intensified per animal and in total.

\section{Acknowledgment}

Paper is financed by the Ministry of Education and Science of the Republic of Serbia, project No. TR-31053. 


\title{
Kako u Srbiji povećati proizvodnju junećeg, jagnjećeg i svinjskog mesa namenjenog domaćim potrebama i izvozu
}

\author{
M. M. Petrović, M. P. Petrović, M. Petrović, S. Aleksić, D. Ostojić-Andrić, \\ V. Pantelić, Ž. Novaković
}

\section{Rezime}

Dugoročna koncepcija razvoja stočarstva treba da se temelji na efikasnosti proizvodnje mesa, preko organizovanja farmera. Za uspešno organizaciono i ekonomsko jačanje farmera važan je pravilan izbor poslovnog povezivanja. Za brdsko planinska područja naše zemlje, u kojima nema organizovanih otkupnih i prerađivačkih kapaciteta i koja su udaljena od gradskih centara, veoma interesantan oblik povezivanja će biti formiranje novih malih preradnih kapaciteta. Stabilne i unapred poznate cene za proizvode stočarstva, kao i dobro postavljeni pariteti cena garancija su za stabilno stočarstvo. Naša dosadašnja iskustva u unapređenju stočarstva i ostvareni rezultati u svetu, transfer tehnologija, sve više nas upućuju da je za brže ukupno poboljšanje stočarstva neophodna bolje organizovana i pojačana stručna i naučna infrastruktura.

U Srbiji je 2010-godine i pored manjeg broja stoke proizvedeno ukupno 384.000 tona junećeg, svinjskog i jagnjećeg mesa, što je za 3,3\% više nego u 2009 . godini, odnosno 6,3 odsto više nego što je bila prosečna proizvodnja od 2001. do 2009. godine. U Srbiji u 2010. bila manja proizvodnja goveđeg, junećeg i telećeg mesa za 4,4 odsto i ovčijeg i jagnjećeg mesa za 7,1 odsto, dok se za 6,8 odsto više proizvodilo svinjsko. 2010-godine, u poređenju sa prosečno ostvarenom proizvodnjom u periodu od 2001. do 2009. proizvedeno je više svih vrsta mesa: svinjskog mesa za 3,1\%, goveđeg i junećeg mesa za 7,5, i ovčijeg i jagnjećeg mesa za $15 \%$.

Sva domaćinstva koja se ozbiljnije bave govedarskom proizvodnjom trebalo bi u narednom periodu organizovati kao gazdinstva za tržišnu proizvodnju mleka, gazdinstva za tržišnu proizvodnju tovne junadi i gazdinstva za kombinovanu tržišnu proizvodnju mleka i junadi za klanje. Osnovnu pažnju u programima razvoja ovčarstva treba posvetiti porodičnom gazdinstvu i novim tehnologijama koje se bave intenziviranjem proizvodnje mesa, mleka i vune na farmama ovaca.

Specijalizovani farmeri za meso, odnosno mleko treba da poseduju od 100500 grla ovaca, kao i odgovarajuću infrastrukturu. Farmeri trojnog smera proizvodnje su tradicionalna domaćinstva koja drže do 20 ili 50 ovaca. Njima treba obezbediti kvalitetan priplodni materijal i svaku drugu pomoć u cilju povećanja njihove proizvodnje. 
Porodične farme bi u narednom desetogodišnjem periodu trebale da drže 50 a zatim do 100 krmača i tove 1000 i više tovljenika. Sve to bi moglo dovesti do povećanja proizvodnje svinjskog mesa po prosečnoj godišnjoj stopi od 2 do $2,5 \%$. Neophodno je odabrati najbolje farme kako bi se formirali elitni, umnožavajući (reproduktivni) i proizvodni (komercijalni) zapati u piramidalnoj organizaciji proizvodnje priplodnih grla i tovljenika.

\section{References}

ALEKSIĆ S., PETROVIĆ M.M., MIŠČEVIĆ B., SRETENOVIĆ LJ., PANTELIĆ V., TOMAŠEVIĆ D. (2006): Production and slaughter characteristics of baby beef type meat in Serbia. Animal Science, British International journal of fundamental and applied research, vol 1. 2. International conference, Quality and safety in meat for consumer: from stable to table, Krakow, Poland, October, 136-138.

MIŠČEVIĆ B., ALEKSIĆ S., PETROVIĆ M.M., LAZAREVIĆ R., JOSIPOVIĆ S., RADETIĆ P., PANTELIĆ., OSTOJIĆ DUŠICA, SMILJAKOVIĆ T. (2006): Strategy of production of beef from farm to table and protection of consumers. Biotechnology in Animal Husbandry, 22, 3-4,11-22.

PETROVIĆ M.M., LAZAREVIĆ R., LAZAREVIĆ LJ., ALEKSIĆ, S., MIŠČEVIĆ B., PERKOVIĆ S. (1997): Proizvodni efekti selekcije aktivne populacije simentalskih goveda u Srbiji. Biotehnology in Animal Husbandry, 13, 3-4, 57-64.

PETROVIĆ M.M., ŽUJOVIĆ M., HOPIĆ S. (2000): Rasni sastav i oplemenjivanje domaćih životinja u Srbiji. Zbornik radova prvog savetovanja "Nauka, praksa i promet u agraru", Vrnjačka Banja, 64-67.

PETROVIĆ M.M, LAZAREVIĆ R., MIŠČEVIĆ B., ALEKSIĆ S., STOJIĆ P. (2001): Cattle production in Serbia at the beginning of new millennium. Biotechnology in Animal Husbandry, 17, 5-6, 87-95.

PETROVIĆ M.M., BOGDANOVIĆ V., PETROVIĆ P.M., RUŽIĆ-MUSLIĆ D., OSTOJIĆ D. (2002): Mogućnosti unapređenja stočarstva brdsko-planinskog područja Srbije. Biotehnologija u stočarstvu, 18, 5-6, 1-8.

PETROVIĆ M.M, LAZAREVIĆ LJ. (2003): The present situation in the livestock production in the Republic of Serbia. Biotehnology in Animal Husbadry, 19, 5-6, 13-23.

PETROVIĆ M.M. (2005): Livestock production in Serbia on way to European Union. Biotehnology in Animal Husbandry, 21, 5-6, 1-8.

PETROVIĆ M.M., SRETENOVIĆ LJ., PANTELIĆ V., ALEKSIĆ S., MIŠČEVIĆ B., BOGDANOVIĆ V., OSTOJIĆ-ANDRIĆ D., PETROVIĆ M. (2006): Results of the aplication of the tehnology of genetic improvement of Simmental cattle population in Serbia. Biotehnology in Animal Husbandry, 22, 1-2, 1-8. 
PETROVIĆ M.M., ALEKSIĆ S., SRETENOVIĆ LJ., MARINKOV G., STOJANOVIĆ LJ., TOMAŠEVIĆ D. (2007): The effect of genotype on quality of beef. Animal Science, British International journal of fundamental and applied research, vol 1. 3. International conference, Quality and safety in meat for consumer: from stable to table, Caunas, Lithuania, 06-07 June, 102-104. PETROVIĆ M., PUŠIĆ M., RADOJKOVIĆ D., MIJATOVIĆ M., RADOVIĆ Č., ŽIVKOVIĆ B. (2006): Phenotypic and genetic variability of quality traits of carcass sides and meat. Biotechnology in Animal Husbandry, 22, 5-6, 1-10.

PETROVIĆ M.P., RUŽIĆ-MUSLIĆ D., MAKSIMOVIĆ N. (2009): Procena gentskog potencijala ovaca u različitim proizvodnim sistemima. Biotechnology in Animal Husbandry, 25, 5-6-1, 421-429.

Received 30 June 2011; accepted for publication 15 August 2011 